\title{
Coral reproduction at Hall Bank, a high latitude coral assemblage in Western Australia
}

\author{
Andrew H. Baird ${ }^{1, *}$, Damian P. Thomson ${ }^{2}$ \\ ${ }^{1}$ ARC Centre of Excellence for Coral Reef Studies, James Cook University, Townsville, QLD 4811, Australia \\ ${ }^{2}$ Commonwealth Scientific and Industrial Research Organization, Oceans and Atmosphere, 35 Stirling Highway, Crawley, \\ WA 6009, Australia
}

\begin{abstract}
Research on coral reproduction has increased dramatically in recent times; however, there remain significant regions, in particular high latitude reefs, where research is limited. For example, the reproductive biology of species in the coral assemblage at Hall Bank, a high latitude site $\left(32^{\circ} \mathrm{S}\right)$ in southern Western Australia, remain unknown. Here, reproductive traits and the likely time of spawning for 12 of the approximately 16 species that occur at Hall Bank were established using histology between March 2009 and March 2011 at 7 discrete time points. Peak reproductive activity most likely occurs in February, as 7 of the 10 species sampled in this month had colonies with mature gametes. The sexuality, mode of larval development and transmission of symbionts were, as expected, consistent with previous work. The reproductive biology of the corals at Hall Bank is consistent with other regions of the Indo-Pacific, supporting the hypothesis that reproductive traits such as sexuality and mode of larval development are evolutionarily conserved and do not vary biogeographically.
\end{abstract}

KEY WORDS: Climate change $\cdot$ Coral reefs $\cdot$ Larval ecology $\cdot$ Marginal reefs $\cdot$ Range shifts

\section{INTRODUCTION}

Heightened interest in high latitude coral assemblages arose in the mid-1990s following the suggestion that high latitude reefs can provide potential sites of refuge from ocean warming (Glynn 1996). Specifically, Glynn (1996) suggested that reefs at high latitudes, moderate depths or in areas with strong currents could provide respite from thermal stress associated with rising ocean temperatures, and thus allow for the persistence or expansion of tropical coral reef species. Indeed, rates of ocean warming since the mid-1990s have remained constant at $1.5^{\circ} \mathrm{C}$ per $100 \mathrm{yr}$ (Hobday \& Pecl 2014) and there is evidence of an associated poleward shift in some tropical and subtropical coral reef species (Verges et al. 2014, Wernberg et al. 2016), including scleractinian corals (Thomson 2010, Yamano et al. 2011, Baird et al. 2012). However, there is also evidence that coral

${ }^{*}$ Corresponding author: andrew.baird@jcu.edu.au assemblages on high latitude reefs do not conform to the same rules of assembly as corals on low latitude coral reefs (Bellwood \& Hughes 2001, Sommer et al. 2014), and recent research has demonstrated not just a poleward shift in the distribution of tropical coral species, but an increasing abundance of resident coral species on some high latitude reefs (Tuckett et al. 2017). Therefore, a better understanding of the biology of species on high latitude reefs is required to assess their potential as sites of refuge from ocean warming.

The reproductive biology of high latitude corals is also of interest because many of these reefs are isolated and are therefore hypothesised to be reliant on self-recruitment or irregular inputs from upstream reefs to sustain populations (Ayre \& Hughes 2004, Noreen et al. 2009, Hoey et al. 2011, Markey et al. 2016, Thomas et al. 2017). Yamaguchi (1986) hypothesised that cooler sea temperatures at high latitudes

(C) The authors 2018. Open Access under Creative Commons by Attribution Licence. Use, distribution and reproduction are unrestricted. Authors and original publication must be credited. 
could prevent sexual reproduction in corals. However, corals living in areas exposed to upwelling, such as the Galapagos Islands (Glynn et al. 1996, 2000) and at high latitudes such as Amakusa, Japan $\left(31^{\circ} \mathrm{N}\right)$ (Nozawa et al. 2006, Mezaki et al. 2007), Lord Howe Island $\left(31^{\circ} \mathrm{S}\right)$ (Baird et al. 2015) and Bermuda $\left(32^{\circ} \mathrm{N}\right)$ (Wyers et al. 1991) are now known to successfully reproduce. Reproduction also occurs in areas considered marginal due to large fluctuations in temperature and salinity, such as the Persian Gulf (Bauman et al. 2011). Nonetheless, there are still many marginal reef areas for which there is no information on coral reproductive biology.

A lack of basic biological data limits our capacity to project the effects of climate change on coral reef assemblage structure and ecosystem function (Keith et al. 2015, Madin et al. 2016b). In particular, there are a number of reproductive traits important in the ecology, evolution and biogeography of corals (Baird et al. 2009b), including sexuality (gonochore or hermaphrodite), mode of larval development (brooding vs. broadcast spawning) and mode of larval nutrition (autotrophic or lecithotrophic). For example, broadcast spawning species have an obligate planktonic period of between 1 and $3 \mathrm{~d}$ and are therefore more likely to be dispersed away from their reef of origin than brooding species that can settle as soon as they are released (Ayre \& Hughes 2004, Figueiredo et al. 2013). Nutritional mode can also influence dispersal, because species with autotrophic larvae can survive for longer in the plankton than species with lecithotrophic larvae (Richmond 1987, Marshall \& Keough 2003). Many of these reproductive traits are highly conserved phylogenetically and do not vary among locations (Baird et al. 2009b, Kerr et al. 2011). Nonetheless, there is a dearth of data from some locations, particularly high latitude reefs. Furthermore, high latitude reefs are isolated, marginal and at the range limits of species distributions, and it is unknown if these conditions foster different ecological traits (Keith et al. 2015).

Understanding the timing of coral reproduction is particularly important for the management and ecology of coral reefs. For example, the effects of human activities such as dredging, coastal construction or the discharge of industry waste on the reproductive success of corals can only be minimised if the reproductive season is known (Baird et al. 2010, 2011). In addition, because many reef fishes and other invertebrates time their reproductive cycles to coincide with the time that corals release larvae into the water column (McCormick 2003), knowledge of coral reproductive cycles may also allow for the implementation of management strategies which benefit not just corals, but many reef taxa. Despite the recognised importance of understanding coral reproductive processes, there remain very few studies documenting the timing of coral reproduction on high latitude reefs (Gilmour et al. 2016).

Research on the reproductive biology of corals in southern Western Australia is limited (Table 1). Crane (1999) investigated the reproductive biology and seasonality of reproduction of 8 species on Rottnest Island. All of these species were observed or inferred to release propagules over a period of 1 to 3 consecutive months between January and May 1998 (Table 1). In addition, Pocillopora damicornis was inferred to release planula larvae from February to April (Ward 1992). Therefore, the peak month of reproductive activity in southern Western Australia appears to be February, when 5 of the 9 species studied to date release propagules (Table 1). This is 1 mo earlier in the year than reefs to the north, such as the Houtman-Abrolhos, where peak reproductive activity is in March (Babcock et al. 1994, Gilmour et al. 2016)

In this study, we documented aspects of the reproductive biology for 12 of approximately 16 coral spe-

Table 1. Summary of research into the reproductive biology of coral species in south Western Australia. Sex: sexuality; mode: mode of larval development; H: hermaphrodite; G: gonochore; S: broadcast spawner; B: brooder; na: could not be determined

\begin{tabular}{|lcclll|}
\hline Species & Sex & Mode & Reproductive information & Reference \\
\hline Paragoniastrea australensis & H & S & Mature gametes and spawning in January and February & Crane (1999) \\
Coelastrea aspera & H & na & Mature gametes in February and March & Crane (1999) \\
Porites lutea & G & na & Mature oocytes in March and April & Crane (1999) \\
Australophyllia wilsoni & H & S & Mature gametes and spawning in February & Crane (1999) \\
Montipora mollis & H & na & Mature gametes in April & Crane (1999) \\
Turbinaria reniformis & G & na & Possible mature gametes in April and May & Crane (1999) \\
Alveopora fenestrata & H & B & Planulae in colonies from February to March & Crane (1999) \\
Acropora sp. & H & na & Mature oocytes in May & Crane (1999) \\
Pocillopora damicornis & H & B & Planulae in colonies from February to April & Ward (1992) \\
\hline
\end{tabular}


cies found at Hall Bank, a small (total area 2 ha) high latitude reef $\left(32^{\circ} 2.002^{\prime} \mathrm{S}, 115^{\circ} 42.957^{\prime} \mathrm{E}\right)$ with high coral cover (mean $=52.6 \pm 0.45 \%$ ) located $20 \mathrm{~km}$ west of the city of Perth (population 1.67 million) (Thomson 2010, Thomson \& Frisch 2010).

\section{MATERIALS AND METHODS}

\section{Reproductive traits}

Many reproductive traits of relevance to the ecology and evolution of corals can be determined using histology, including the sexuality, mode of larval development and mode of transmission of symbionts. If both types of gametes (i.e. oocytes and sperm) are present in the histological sections, either in the same polyp or separate polyps, then the colony is a hermaphrodite; if only one type of gamete is present and those gametes are mature, the colony is classified as a gonochore. Larvae can be distinguished from oocytes because there are distinct layers of cells in a larvae, i.e. an endoderm and an ectoderm. If larvae are observed in the sections then the colony is a brooder. Symbiotic algae are also visible in histology sections; if they are present in in the oocytes the species is said to have vertical transmission of the symbionts (symbionts acquired from parent). If not, it has horizontal transmission (symbionts acquired from the environment).

\section{Timing of reproduction}

To determine the reproductive condition of colonies, one $5 \mathrm{~cm}$ branch or $25 \mathrm{~cm}^{2}$ nubbin was collected from each colony on several dates over a $2 \mathrm{yr}$ period commencing in March 2009. Sampling was opportunistic, with different colonies, a different number of colonies and different number of species sampled on each occasion (see Table 2 for dates, species and sample size of the various collections). Samples were preserved in $10 \%$ seawater formalin, then decalcified in a mixture of $90 \%$ water and $10 \%$ formic acid and preserved in $70 \%$ ethanol. Sections of the decalcified samples were embedded in wax following dissections, sectioned at $7 \mu \mathrm{m}$ thickness and 3 to 4 sections approximately $50 \mu \mathrm{m}$ apart were mounted on slides. Slides were stained using Mayer's haematoxylin and Young's eosin-erythrosine, and gametes were classified as mature (stage IV) or immature (stage I to III) following Baird et al. (2011).

\section{Environmental variables associated with coral spawning}

Environmental variables hypothesized to serve as proximate cues to synchronise spawning (see Keith et al. 2016) were collated and their association with the timing of spawning on Hall Bank illustrated graphically. These variables were daily in situ water temperatures $\left({ }^{\circ} \mathrm{C}\right)$, solar radiation $\left(\mathrm{MJ} \mathrm{m}^{-2}\right)$, rainfall $(\mathrm{mm})$, and wind speeds $\left(\mathrm{km} \mathrm{h}^{-1}\right)$. These data were obtained for the Fremantle station (located approximately $2 \mathrm{~km}$ east of Hall Bank) for the period 1890 to 2000 from the Australian Bureau of Meteorology (www.bom.gov.au/climate/averages/tables/cw_009017. shtml).

\section{Species identifications}

Species were identified in the field following Veron (2000). The currently accepted names for these species were then determined using either the World Register of Marine Species (Hoeksema 2018) or the most recent peer-reviewed research (e.g. Arrigoni et al. 2014).

\section{RESULTS}

\section{Reproductive traits and timing of gamete release}

Australophyllia wilsoni was sampled on 2 occasions. In February 2010, 1 of the 4 colonies sampled had mature ooctyes and spermaries in the same polyp, from which it was determined that it is a hermaphrodite (Table 1, Fig. 1 a). Coelastrea palauensis was sampled on 4 occasions and no gametes were observed in any colonies, including all 6 colonies sampled in February 2010. Therefore, it was not possible to determine when C. palauensis spawns or any other aspect of its reproductive biology. Coscinaraea mcneilli was sampled once in February 2010 when all 3 colonies contained either mature oocytes or mature testes, indicting the species is a gonochore (Table 2, Fig. 1b). Cyphastrea serailia was sampled once and 5 of the 6 colonies contained immature ooctyes and spermaries (Table 2, Fig. 1c). Dipsastraea amicorum was sampled once in February 2010 when all 4 colonies contained mature oocytes and spermaries (Table 2, Fig. 1d). Duncanopsammia peltata was sampled on 2 occasions. In February 2010, 1 of the 2 colonies sampled had mature spermaries suggesting the species is a gonochore (Table 2, Fig. 1e). Goniopora pendulus was 

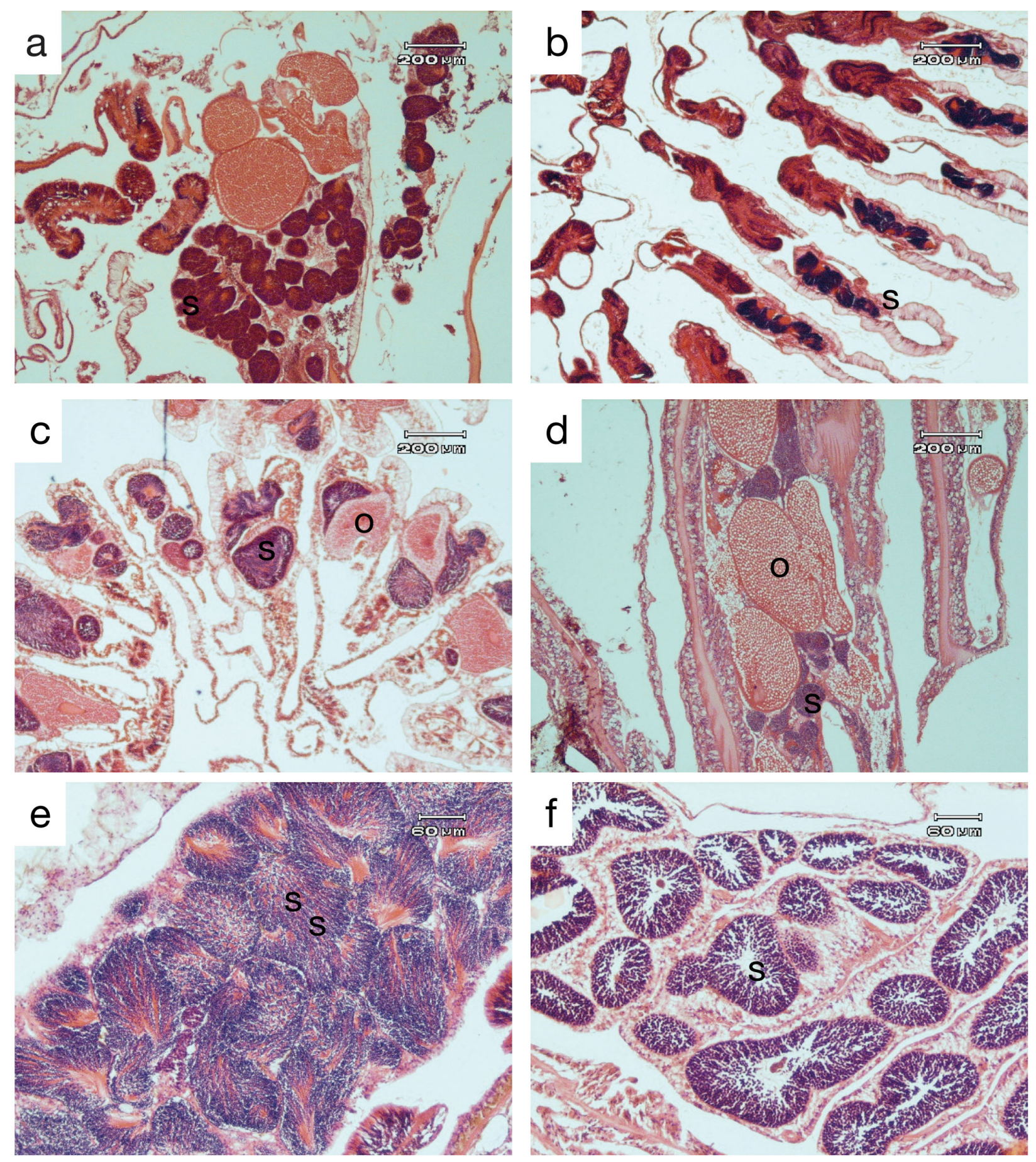

Fig. 1. Light micrographs illustrating the gametes of the species examined with histology. (a) Australophyllia wilsoni, (b) Coscinaraea mcneilli, (c) Cyphastrea serailia, (d) Dipsastraea amicorum, (e) Duncanop-sammia peltata and (f) Goniopora pendulus. o: ooctyes; s: spermaries

sampled once in February 2010 and the one colony sampled had mature spermaries, suggesting the species is a gonochore (Table 2, Fig. 1f). Montipora mollis was sampled once in February 2010 and the one colony sampled had mature oocytes and spermaries, suggesting the species is an hermaphrodite (Table 2, Fig. 2a). Paragoniastrea australensis was sampled on 4 occasions. No mature gametes were observed; however, 4 of the 13 colonies sampled in December 2009 had immature gametes and the stage of development 


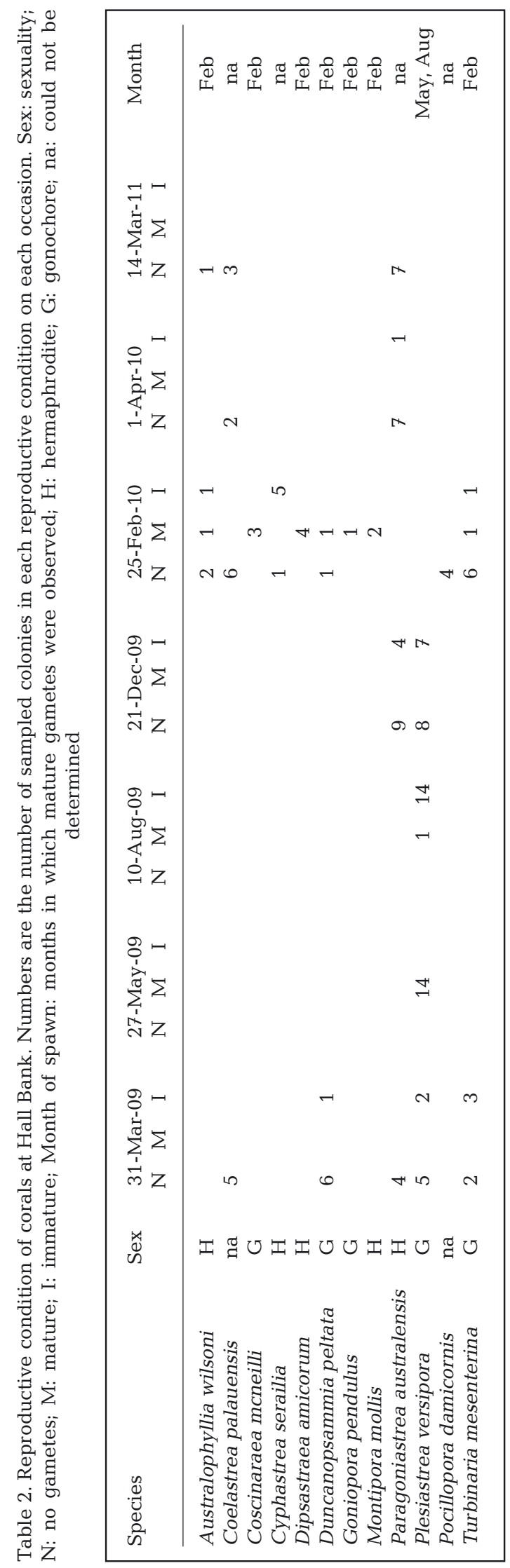

suggested they would spawn sometime in the next 1 or 2 months (Table 2, Fig. 2b). Plesiastrea versipora was sampled on 4 occasions (Table 2) and had immature gametes on each occasion except in May 2009, when all 14 colonies sample had either mature oocytes (Fig. 2c) or spermaries (Fig. 2d) indicating the species is a gonochore. One colony had mature oocytes in August 2009, indeed, 2 distinct stages of oocyte development were visible in the oocytes of this colony (Fig. 2c). Pocillopora damicornis was samples once in February 2009 and no gametes were observed. Turbinaria mesenterina was sampled twice; mature spermaries (Table 2, Fig. 2f) and oocytes (Table 2, Fig. 2f) were observed in February 2009 (Table 2, Fig. 2f), indicating the species is a gonochore.

No larvae were observed in the sections of those species for which mature gametes were detected. Symbiodinium were only observed in the oocytes of M. mollis (Fig. 2a), suggesting all but this species have horizontal transmission of symbionts.

\section{Environmental conditions during spawning}

The peak of gamete maturity in February coincided with the highest sea temperature (Fig. 3a), high solar radiation (Fig. 3b), low rainfall (Fig. 3c) and low morning wind speeds (Fig. 3d).

\section{DISCUSSION}

We documented the reproductive biology of 12 of the approximately 16 coral species at Hall Bank, Western Australia. Peak reproductive activity at Hall Bank occurs in February, with 7 of the 10 species sampled in this month found to contain mature gametes. These data are in strong agreement with those from nearby Rottnest Island, where 5 of the 9 species examined to date release propagules in February (Table 1). The peak month of reproductive activity is approximately 1 mo earlier than on reefs further north in Western Australia (Babcock et al. 1994, Gilmour et al. 2016). This is in contrast to patterns on the east coast of Australia (Baird et al. 2015) and in Japan (Baird et al. 2009a), where peak spawning on high latitude reefs is typically 1 mo later than on low latitude reefs. The peak in gamete maturity coincided with high sea temperature and solar radiation, and low morning wind speeds and rainfall (Fig. 3). This peak in gamete maturity is in strong agreement with recent research on the high latitude reefs of Rapa Nui 

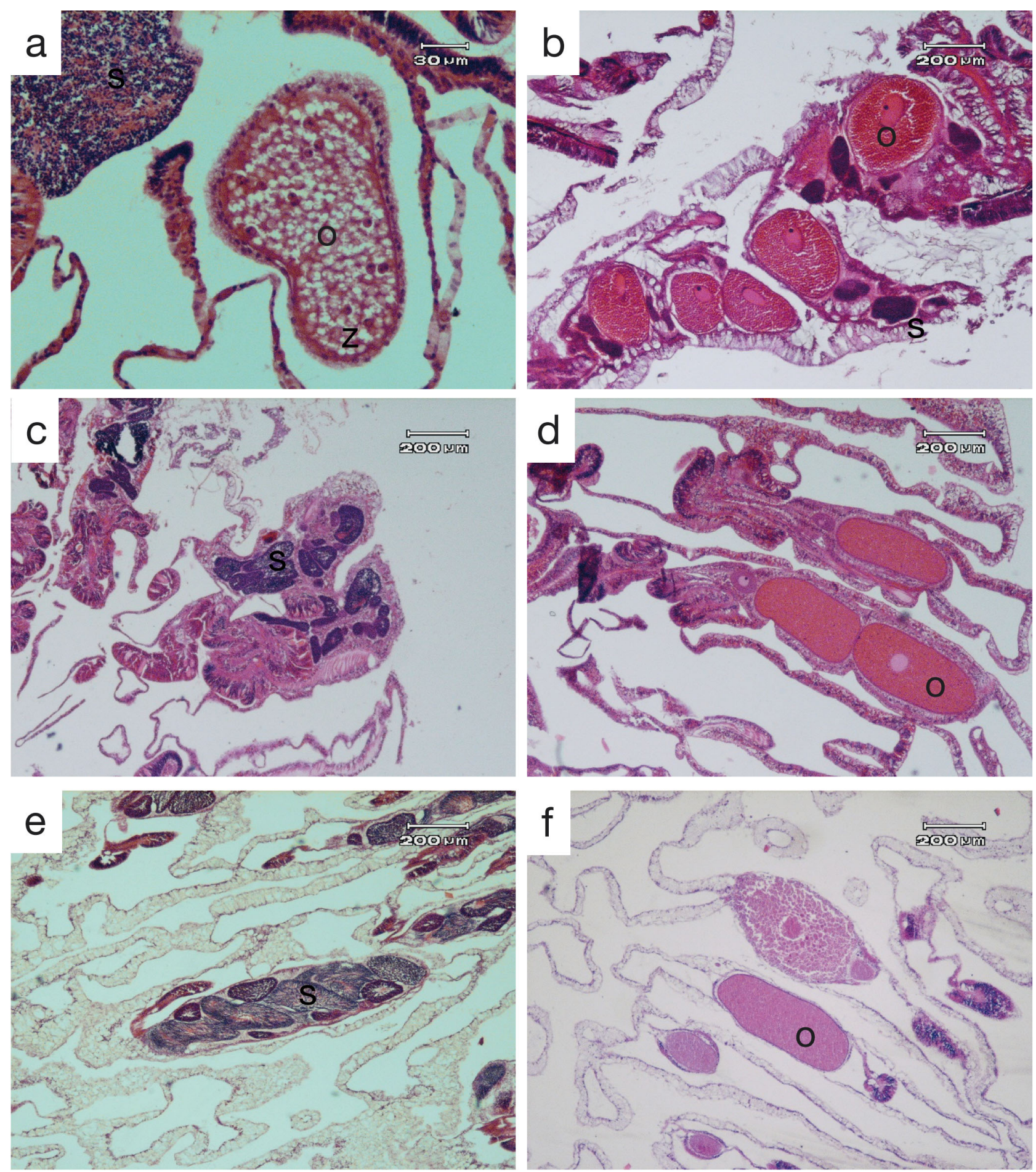

Fig. 2. (a) Montipora mollis, (b) Paragoniastrea australensis, (c) Plesiastrea versipora male, (d) Plesiastrea versipora female, (e) Turbinaria mesenterina male and (f) Turbinaria mesenterina female. o: ooctyes; s: spermaries; z: zooxanthellae

in the eastern Pacific, where 2 species of broadcast spawning corals were observed to spawn at times of low wind speeds and prior to the summer maximum seawater temperatures (Buck-Wiese et al. 2018). One explanation for the difference in latitudinal patterns of spawning on the east and west coast might be the contrasting changes in water temperature and solar radiation between spring and autumn. For example, on the east coast of Australia and in Japan, peak spawning period occurs when water temperatures 

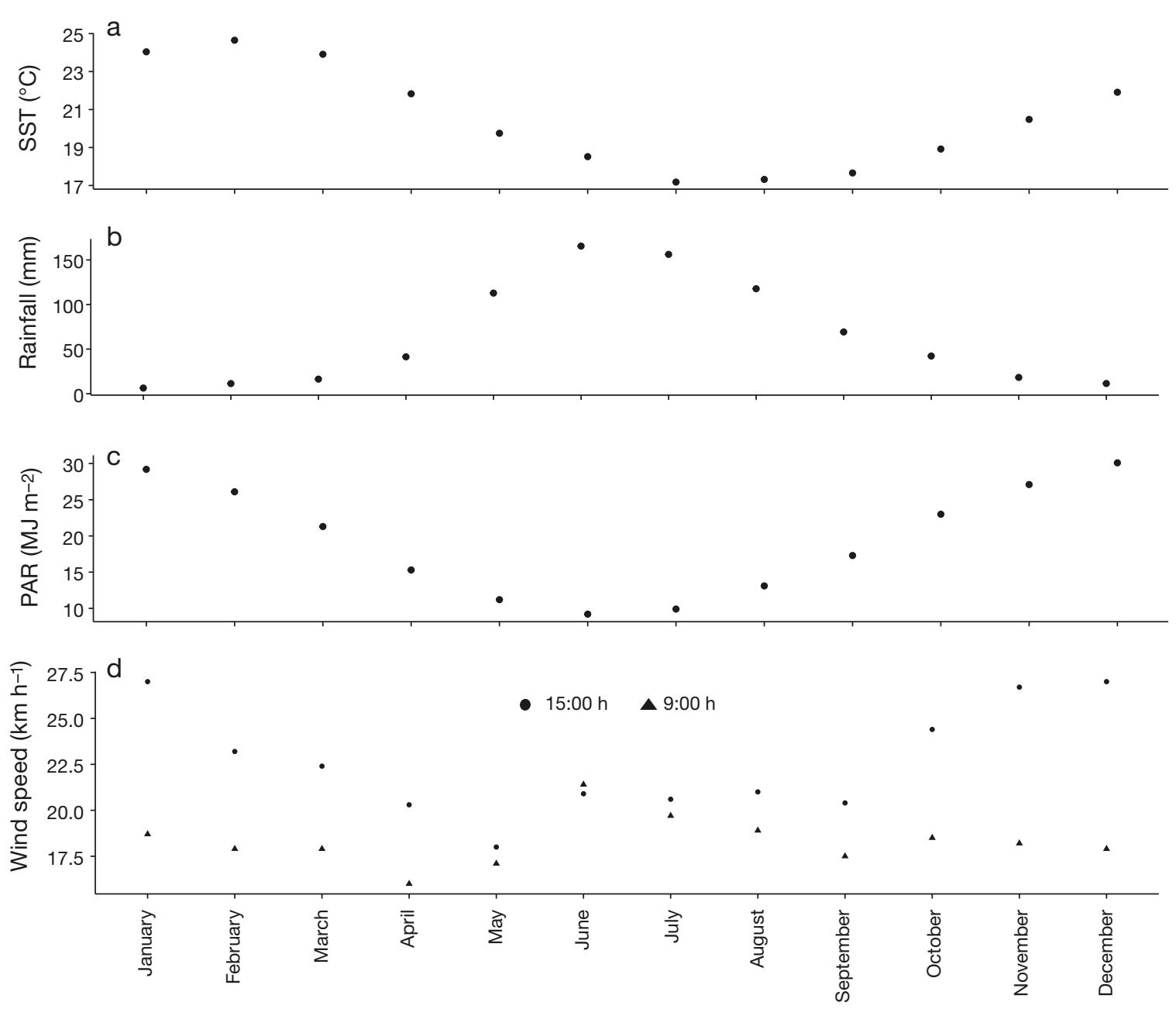

Fig. 3. Environmental variables hypothesised to be involved in synchronising coral spawning: (a) mean monthly sea surface temperature (SST) for the period 1982 to 2010, (b) mean monthly rainfall, (c) mean monthly photosynthetically active radiation (PAR) and (d) mean monthly wind speeds for the period 1999-2010 (Data sources are listed in 'Materials and methods')

and solar radiation levels are rising (spring). In contrast, on the west coast of Australia the peak spawning period occurs when water temperatures and solar radiation levels are decreasing (autumn). Therefore, peak spawning on high latitude reefs on both the east and west coast of Australia occurs when water temperatures are at the yearly maxima, presumably in order to maximise both fertilization success and larval survivorship (Woolsey et al. 2015). Low wind speeds and high rainfall have also previously been associated with the time of spawning, however, more recent work on spawning cues in the Scleractinia does not support such an association (see discussion in Keith et al. 2016).

Plesiastrea versipora was sampled on 4 occasions and had immature gametes on each occasion except in May 2009, when all 14 colonies sample were mature. In August 2009, 2 stages of oocytes were visible
(Fig. 2d). These data suggest that, similar to populations on the east coast of Australia (Madsen et al. 2014), the oogenic cycle lasts longer than 1 yr.

Four species were common between this study and previous work at Rottnest Island (Tables $1 \& 2$ ). Similar to Crane (1999), our data indicates that Australophyllia wilsoni spawns in February, and immature oocytes in our samples of Paragoniastrea australensis are consistent with a January or February spawning as observed by Crane (1999). In contrast to Crane (1999), our data indicate a February rather than an April spawn in Montipora mollis. In contrast to Ward (1992) we saw no planulae in Pocillopora damicornis in February. When these 2 data sets are combined, a total of 18 species have now been examined in southern Western Australia, 12 of which have mature gametes in February. In addition, there is some spawning in every month from January to May. 
The sexuality and mode of reproduction of each species were similar to previous records (Baird et al. 2009a) or were in line with expectations based on taxonomy. For example, Goniopora pendulus, Duncanopsammia peltata, Coscinaraea mcneilli and Plesiastrea versipora were all gonochores along with other species within their respective families (Baird et al. 2009a, Madin et al. 2016a) These data support the hypothesis that sexuality is a highly conserved trait at the family level in the Scleractinia (Kerr et al. 2011).

In conclusion, the reproductive biology of the species at Hall Bank was consistent with similar or related species in tropical regions, suggesting that the selective pressures on reproductive traits on high latitude reefs are not significantly different than in the tropics. The reproductive season in south Western Australia extends over at least $5 \mathrm{mo}$, similar to reefs further north in Western Australia (Gilmour et al. 2016) and on the Great Barrier Reef (Baird et al. $2009 b$ ). The seasonal nature of coral reproduction suggests that processes that affect reproductive success, such as dredging, should be restricted to months outside of this reproductive season.

Acknowledgements. This project was funded by Australian Research Council Centre of Excellence programme and the CSIRO Oceans and Atmosphere. We thank Sue Reilly for processing the histological samples and Ryan Crossing, Fiona Graham, Douglas Bearham and Stelios Kondylas for assistance with field collections.

\section{LITERATURE CITED}

Arrigoni R, Kitano YF, Stolarski J, Hoeksema BW and others (2014) A phylogeny reconstruction of the Dendrophylliidae (Cnidaria, Scleractinia) based on molecular and micromorphological criteria, and its ecological implications. Zool Scr 43:661-688

Ayre DJ, Hughes TP (2004) Climate change, genotypic diversity and gene flow in reef-building corals. Ecol Lett $7: 273-278$

Babcock RC, Willis BL, Simpson CJ (1994) Mass spawning of corals on a high latitude coral reef. Coral Reefs 13: 161-169

Baird AH, Birrell CL, Hughes TP, McDonald A and others (2009a) Latitudinal variation in reproductive synchrony in Acropora assemblages: Japan vs. Australia. Galaxea 11:101-108

Baird AH, Guest JR, Willis BL (2009b) Systematic and biogeographical patterns in the reproductive biology of scleractinian corals. Annu Rev Ecol Evol Syst 40:551-571

Baird AH, Kospartov MC, Purcell S (2010) Reproductive synchrony in Acropora assemblages on reefs of New Caledonia. Pac Sci 64:405-412

Baird AH, Blakeway DR, Hurley TJ, Stoddart JA (2011) Seasonality of coral reproduction in the Dampier Archipelago, northern Western Australia. Mar Biol 158:275-285
Baird AH, Sommer B, Madin JS (2012) Pole-ward range expansion of Acropora spp. along the east coast of Australia. Coral Reefs 31:1063

Baird AH, Cumbo VR, Gudge S, Keith SA, Maynard JA, Tan $\mathrm{CH}$, Woolsey ES (2015) Coral reproduction on the world's southernmost reef at Lord Howe Island, Australia. Aquat Biol 23:275-284

Bauman AG, Baird AH, Cavalcante GH (2011) Coral reproduction in the world's warmest reefs: southern Persian Gulf (Dubai, United Arab Emirates). Coral Reefs 30: 405-413

*B Bellwood DR, Hughes TP (2001) Regional-scale assembly rules and biodiversity of coral reefs. Science 292: 1532-1534

*Buck-Wiese H, Burgués I, Medrano A, Navarrete-Fernandez T, Garcia M, Wieters EA (2018) Patterns in sexual reproduction of the dominant scleractinian corals at Rapa Nui (Easter Island): Pocillopora verrucosa and Porites lobata. Aquat Biol 27:1-11

Crane KR (1999) Reproductive biology of scleractinian corals at Rottnest Island, Western Australia. Honours thesis, Murdoch University, Perth

Figueiredo J, Baird AH, Connolly SR (2013) Synthesizing larval competence dynamics and reef-scale retention reveals a high potential for self-recruitment in corals. Ecology 94:650-659

* Gilmour J, Speed CW, Babcock R (2016) Coral reproduction in Western Australia. PeerJ 4:e2010

*Glynn PW (1996) Coral reef bleaching: facts, hypotheses and implications. Glob Change Biol 2:495-509

Glynn PW, Colley SB, Gassman NJ, Black K, Cortes J, Mate JL (1996) Reef coral reproduction in the eastern Pacific: Costa Rica, Panama, and Galapagos Islands (Ecuador). 3. Agariciidae (Pavona gigantea and Gardineroseris planulata). Mar Biol 125:579-601

KGlynn PW, Colley SB, Ting JH, Mate JL, Guzman HM (2000) Reef coral reproduction in the eastern Pacific: Costa Rica, Panama, and Galapagos Islands (Ecuador). 4. Agariciidae, recruitment and recovery of Pavona varians and Pavona sp. a. Mar Biol 136:785-805

Hobday AJ, Pecl GT (2014) Identification of global marine hotspots: sentinels for change and vanguards for adaptation action. Rev Fish Biol Fish 24:415-425

Hoeksema B (2018) World register of marine species. www. marinespecies.org/aphia.php?p=taxdetails\&id=206488 (accessed on 16 Feb 2018)

*Hoey AS, Pratchett MS, Cvitanovic C (2011) High macroalgal cover and low coral recruitment undermines the potential resilience of the world's southernmost coral reef assemblages. PLOS ONE 6:e25824

Keith SA, Woolsey ES, Madin JS, Byrne M, Baird AH (2015) Differential establishment potential of species predicts a shift in coral assemblage structure across a biogeographic barrier. Ecography 38:1225-1234

* Keith SA, Maynard JA, Edwards AJ, Guest JR and others (2016) Coral mass spawning predicted by rapid seasonal rise in ocean temperature. Proc R Soc B 283:20160011

Kerr AM, Baird AH, Hughes TP (2011) Correlated evolution of sex and reproductive mode in corals (Anthozoa: Scleractinia). Proc R Soc B 278:75-81

Madin JS, Anderson KD, Andreasen MH, Bridge TCL and others (2016a) The coral trait database, a curated database of trait information for coral species from the global oceans. Sci Data 3:160017

*Madin JS, Hoogenboom MO, Connolly SR, Darling ES and 
others (2016b) A trait-based approach to advance coral reef science. Trends Ecol Evol 31:419-428

Madsen A, Madin JS, Tan CH, Baird AH (2014) The reproductive biology of the scleractinian coral Plesiastrea versipora, in Sydney Harbour. Sex Early Dev Aquat Org 1: 25-33

Markey KL, Abdo DA, Evans SN, Bosserelle C (2016) Keeping it local: dispersal limitations of coral larvae to the high latitude coral reefs of the Houtman Abrolhos Islands. PLOS ONE 11:e0147628

Marshall DJ, Keough MJ (2003) Variation in the dispersal potential of non-feeding invertebrate larvae: the desperate larva hypothesis and larval size. Mar Ecol Prog Ser 255:145-153

McCormick MI (2003) Consumption of coral propagules after mass spawning enhances larval quality of damselfish through maternal effects. Oecologia 136:37-45

Mezaki T, Hayashi T, Iwase F, Nakachi S, Nozawa Y, Miyamoto M, Tominaga M (2007) Spawning patterns of high latitude scleractinian corals from 2002 to 2006 at Nishidomari, Otsuki, Kochi, Japan. Kuroshio Biosph 3: 33-47 (in Japanese with English Abstract)

Noreen AME, Harrison PL, Van Oppen MJH (2009) Genetic diversity and connectivity in a brooding reef coral at the limit of its distribution. Proc R Soc B 276:3927-3935

Nozawa Y, Tokeshi M, Nojima S (2006) Reproduction and recruitment of scleractinian corals in a high-latitude coral community, Amakusa, southwestern Japan. Mar Biol 149:1047-1058

Richmond RH (1987) Energetics, competency, and longdistance dispersal of planula larvae of the coral Pocillopora damicornis. Mar Biol 93:527-533

Sommer B, Harrison PL, Beger M, Pandolfi JM (2014) Traitmediated environmental filtering drives assembly at biogeographic transition zones. Ecology 95:1000-1009

Thomas L, Jason Kennington W, Evans R, Kendrick G, Stat

Editorial responsibility: Judith Grassle,

New Brunswick, New Jersey, USA
M (2017) Restricted gene flow and local adaptation highlight the vulnerability of high-latitude reefs to rapid environmental change. Glob Change Biol 23:2197-2205

* Thomson DP (2010) Range extension of the hard coral Goniopora norfolkensis (Veron \& Pichon 1982) to the southeast Indian Ocean. J R Soc West Aust 93:81-83

Thomson DP, Frisch AJ (2010) Extraordinarily high coral cover on a nearshore, high-latitude reef in south-west Australia. Coral Reefs 29:923-927

* Tuckett CA, de Bettignies T, Fromont J, Wernberg T (2017) Expansion of corals on temperate reefs: direct and indirect effects of marine heatwaves. Coral Reefs 36:947-956

*Verges A, Steinberg PD, Hay ME, Poore AGB and others (2014) The tropicalization of temperate marine ecosystems: climate-mediated changes in herbivory and community phase shifts. Proc R Soc B 281:20140846

Veron JEN (2000) Corals of the world. AIMS, Townsville

*Ward S (1992) Evidence for broadcast spawning as well as brooding in the scleractinian coral Pocillopora damicornis. Mar Biol 112:641-646

*Wernberg T, Bennett S, Babcock RC, de Bettignies T and others (2016) Climate-driven regime shift of a temperate marine ecosystem. Science 353:169-172

Woolsey ES, Keith SA, Byrne M, Schmidt-Roach S, Baird AH (2015) Latitudinal variation in thermal tolerance thresholds of early life stages of corals. Coral Reefs 34:471-478

* Wyers SC, Barnes HS, Smith SR (1991) Spawning of hermatypic corals in Bermuda: a pilot study. Hydrobiologia 216-217:109-116

* Yamaguchi M (1986) Acanthaster planci infestations of reefs and coral assemblages in Japan: a retrospective analysis of control efforts. Coral Reefs 5:23-30

*Yamano H, Sugihara K, Nomura K (2011) Rapid poleward range expansion of tropical reef corals in response to rising sea surface temperatures. Geophys Res Lett 38: L04601

Submitted: December 5, 2017; Accepted: April 11, 2018

Proofs received from author(s): May 25, 2018 